\title{
Where are the Limits to the Enlargement of the European Union?
}

\author{
Miroslav N. Jovanović \\ UN Economic Commission for Europe
}

\begin{abstract}
Protection of the Single M arket, monetary integration, institutional and pol icy reform, as well as enlargement are hot topics in the European Union. This article consi ders only the economic dimensi on of the enlargement. Five coun tries with economies in transition (the Czech Republic, Estonia, Hungary, Poland and Slovenia), and one market economy (Cyprus) negotiate full mem bership with the European Union. Although there are general grounds for the enlargement of the European Union, the process will be much slower than expected by the politicians in both the E uropean Union and the acceding coun tries. The reasons for such conclusi on include high standards that come from the ever growing acquis communautaire which are costly to introduce, imple -
\end{abstract}

\footnotetext{
*Correspondence Address: UN ECE, Trade Division, Palais des Nations, 1211 Geneva 10, Switzerland, (F ax) 0041229170037, (E-mail) miroslav.J ovanovic@unece.org The first version of this article was presented at a symposium on Cyprus and the European Union, Intercollege, Nicosia, 7-9 M ay 1998.

** I have benefited from discussions with many friends and colleagues, but I owe special gratitude to M yung-gun Choo, Zizis Haritos, Valerio Lintner, Constantinos Lycourgos, M arina Rossi, M ary Unwin and Ana Yturriaga. Statistical material was kindly supplied by Liljana Figar, Vlastimil Gejdoš, Gertrúd Goór, Niki Hadjiantoni, Iacovos Ioannou, Tauno Kangur, Kata M áthé, M ai Tavlik and J acek Tchorzewski.Christina O 'Shaughnessy edited the text. Nonetheless, the views expressed are my own and do not reflect the position of the organization for which I work.
}

(C1999 - Institute for International E conomics, Sejong Institution. All rights reserved. 
ment and enforce. (JE L Classification: F 15) ४Key Words : monetary integration, institutional and political reform, EU>

\section{Introduction}

The objective of this article is to contribute to the ongoing discussion about the potential enlargement of the European Union $(E U)^{1}$ as five transition economies, the Czech Republic, Estonia, Hungary, Poland and Slovenia, as well as one market economy, Cyprus, negotiate full membership with EU. The article focuses on the economic dimension of the enlargement and provides a survey of how these countries satisfy the economic criteria for accession. The general terms for entry are known, but the specific terms are being negotiated. However, prior to any further enlargement, EU will have to settle two internal issues. First, in accordance with the $M$ aastricht Treaty, the Union became an E conomic and M onetary U nion (EM U) for 11 member countries on January 1, 1999. The second issue, institutional change, was not settled by the Treaty of Amsterdam, but postponed more or less indefinitely. EU has to change its organizational structure in preparation for the decades to come when it is expected to enlarge and even double the number of its member countries.

This article begins by looking at the strategic goals of EU. It than examines the economic structure in the acceding countries. Entry criteria and cost and benefits that may come from EU enlargement are analyzed in separate sections. The conclusion is that the acceding transition countries do not satisfy most of the economic criteria for EU entry at the moment. Some of these countries may in the future need to invest a lot of effort, time and money of their own to comply with the economic requirements for full membership. Cyprus has no problem in satisfying the economic conditions for EU entry.

\section{Priorities of the European Union}

The European Union is at an important turning point. On the political

1. The European Union is referred to as the organizational habitat for European integration that started with the Treaty of Rome. 
front, it was unable to solve either the neighboring Yugoslav black hole or the crisis in Albania. In the economic field it is not capable of creating new jobs and reducing unemployment. EMU is the Union's major project for the 1990s. Therefore, EU countries are trying hard to reach the goal prescribed by the letter of the $M$ aastricht Treaty. At the same time, there is a political determination to enlarge EU by accepting $5+1$ countries. In order to face all those challenges, EU has to change. However, it is not yet known what shape the new EU will take in the future. It is possible that it may change beyond recognition. The stakes are therefore quite high.

A series of bilateral inter-governmental conferences between EU on the one hand and each of the select group of $5+1$ countries started in London on $31 \mathrm{M}$ arch 1998 with the goal of negotiating enlargement of EU. At the same time, EU opened the accession process with five other central and eastern European countries (Bulgaria, Latvia, Lithuania, Romania and Slovakia). While there is no question about Cyprus being a market economy (one of the conditions for EU membership), ${ }^{2}$ there are still concerns about the acceding countries in transition. The economic transition towards a marketbased system and decentralized decision-making gives the transition countries the advantage of being fully included in the international trading system which is based on market forces. However, the success of integration of the transition economies into the international trading system depends on at least two variables. The first is the transformation of their economic system into a liberal market one, while the other hinges on the openness of EU and other western markets for goods and services. ${ }^{3}$

The EU has four general strategic goals:

- The creation of the Single M arket was the objective for the 1985-92 period. Following that, ongoing goals include making rules more transparent and effective, as well as removing the remaining and new market distortions. These areas include competition, taxation, telecommunications, company statute and the environment in order to deliver the full benefits

2. After the change of government in September 1998, M alta would like to reopen accession negotiations with $\mathrm{EU}$.

3. The transition process has three features: liberalization, stabilization and modernization. It is much longer and costlier than foreseen at the end of 1980s, when all these changes started to take place. 
of the Single $M$ arket to the citizens.

- Monetary integration is the major new project and goal of EU in the 1990s till 2002.

- Institutional reform of EU must precede any future enlargement. The same holds for the reform of EU policy in agriculture.

- If all goes well with the previous three goals, enlargement of EU will be the priority project for the Union in the first decade(s) of the new centur $y$. This, however, does not exclude the possibility of parallel negotiations on the institutional reform and enlargement of EU. N onetheless, the institutional reform will have to precede the actual enlargement of EU.

\section{Economic Structure of the Acceding Countries}

The acceding $5+1$ countries would bring over 60 million additional consumers into EU. However, some of those countries are so small that the EU economy would hardly notice their entry. As for the level of development measured by GDP per capita in purchasing power parity (PPP), the $5+1$ countries are at a lower level of development than the EU average (Table 1). However, there are two distinct groups of potential entrants. Cyprus, Slovenia and the Czech Republic are in the group of relatively developed potential entrants, while Estonia, Hungary and Poland are in the group of the potential entrants with a GDP per capita which is just one third of the EU average. As

\section{Table 1}

GDP per Capita and Population in Acceding Countries and in the European Union (1996)

\begin{tabular}{|l|c|c|}
\hline Country & \$PPP & Population (million) \\
\hline EU & 19,250 & 371.60 \\
Slovenia & 13,200 & 1.99 \\
Czech Republic & 12,710 & 10.30 \\
Cyprus & 11,989 & 0.74 \\
Hungary & 6,845 & 10.14 \\
Poland & 6,663 & 38.60 \\
Estonia & 6,612 & 1.45 \\
\hline
\end{tabular}

Source: National sources; The Economist, December 20 , 1997, p. 29. 
such, the countries from the second group would be eligible for large regional funds from EU. This is particularly relevant for Poland because of its large population and relative 'backwardness' measured by the GDP per capita.

The economic structure of the acceding countries shows that services are the predominant economic sector (Table 2). The same is true for EU. However, there are concerns regarding agriculture. The contribution of this sector to the GDP in $5+1$ countries is twice as big as is the case in EU.

\section{Table 2}

\section{Structure of the GDP in the European Union and} the Acceding Countries (1997)

(unit: \%)

\begin{tabular}{|l|c|c|c|}
\hline Country & Agriculture & M anufacturing & Services \\
\hline EU & 2.4 & 31.4 & 66.1 \\
Cyprus & 5.0 & 11.3 & 73.0 \\
Czech Republic & 5.0 & 26.6 & 54.4 \\
Estonia & 5.8 & 15.1 & 58.7 \\
Hungary & 5.2 & 25.0 & 54.2 \\
Poland & 4.8 & 25.0 & 49.7 \\
Slovenia & 3.7 & 24.8 & 51.0 \\
\hline
\end{tabular}

Note: In certain cases data do not add up to 100 owing to the different statistical record of construction, water and energy.

Source: National sources and Eurostat

The situation in the labor market of the $5+1$ countries is uneven (Table 3 ). The unemployment problem is on average as pressing in Poland and Hungary as it is in EU. Apart from Slovenia, other acceding countries have a significantly lower unemployment problem as recorded by the official statistics. As for the sectoral structure of employment, more than a quarter of the labor force in Poland is in agriculture. ${ }^{4}$ This is five times the EU average. A quarter of Poland's labor employed in agriculture contributes less than $5 \%$ to the GDP. This compares with figures of 5 and $2 \%$ respectively, in $E U(15)$. If labor migrates to the cities, this may increase productivity in Polish farming.

4. Agriculture employs $34.4 \%$ of the Romanian labour force, while the same ratio in Bulgaria is $23.2 \%$ and $23.8 \%$ in Lithuania. 
Table 3

Unemployment Rate and Share of Agriculture in Total Employment in the Acceding Countries (1997)

(unit: $\%$

\begin{tabular}{|l|c|c|}
\hline Country & Unemployment Rate & Agriculture in Total Employment \\
\hline EU & 10.7 & 5.3 \\
Cyprus & 3.4 & 9.9 \\
Czech Republic & 4.3 & 5.6 \\
Estonia & 3.0 & 9.1 \\
Hungary & 8.7 & 7.9 \\
Poland & 10.3 & 25.3 \\
Slovenia & 7.4 & 12.0 \\
\hline
\end{tabular}

Source: National sources and Eurostat

However, if there are no new jobs in manufacturing and services sectors to absorb such an inflow, significant tensions may take place in society.

\section{Entry Criteria}

'Any European state may apply to become a M ember of the Union' (Article $\mathrm{O}$ of the $\mathrm{M}$ aastricht Treaty). ${ }^{5}$ That is the only $\mathrm{M}$ aastricht Treaty based (sufficient) condition for a country to be considered for full membership of EU. In addition, there are several other necessary and tacit, economic and political requirements for entry. These were formally defined during the Copenhagen summit in 1993. The potential candidate country must fulfil three conditions. It must have a functioning market economy, a democratic political system and accept the acquis communautaire.

A part from the Czech Republic and Slovakia, not a single transition country had a fully functioning market economy even before they became centrally planned countries (van Brabant, [1996]). Entry into EU, in particular an early

5. Article 237 of the Treaty of Rome regulates the same issue in the identical way. Nonetheless, the unresolved question is what are the European states? Are those the ones that are the members of the UN Economic Commission for Europe (include among others Canada and Uzbekistan)? D oes religion matter? 
entry by transition economies, could cause a serious external shock for any transition country. Their economies are not yet fully adjusted to the market type economic system and their manufacturing and services sectors are still fragile. Early entry into EU without a full macroeconomic stabilization and modernization of the output structure may be disastrous. Countries that pass through the 'transition phase' would not be able to withstand strict rules for competition with EU producers in most industries. Transition fatigue is apparent in all transition countries and is obvious in the return of the 'recycled' communists to office. Therefore, the entry into $\mathrm{EU}$ in a distant future needs to be thoroughly thought through and coupled with serious preparations.

The second condition is that the prospective country has a stable democratic political system. This means a multi-party parliament; rule of law and respect for human and minority rights. It also includes good neighborly relations and no territorial disputes. With regard to the last, not a single transition country passes the test. The northern part of Cyprus is still occupied. Nor do certain EU countries fare well here: just consider Northern Ireland. However, the advantage is that they are already in EU. EU is interested in resolving pressing problems in the region. There are, however, some signs that the prospect of EU membership may ease tensions, as happened with Hungary and Romania in 1996. EU needs to assist transition countries in order to create peaceful and prosperous neighborhood for itself in the future. The question no longer is whether transition countries need to be incorporated into EU. The question is the cost of expansion of EU to the existing members, as well as when and how long the enlargement may take?

The third condition relates to the acquis communautaire or Community patrimony, the whole body of the established EU laws, policies and practice. The acceding country must accept, implement and enforce that set of rules. ${ }^{6}$ The belief that skilful national diplomacy and bargaining may pro-

6. The Treaty of Westphalia [1648] ended the Thirty Years' War. The Treaty established the principle that the states are free to do whatever they like within their own borders (for example, choice of religion). However, only those measures that have external implications are the concern of foreigners. The acquis communautaire is a clear demand for harmonization. However, 'demand for harmonization is by and large ill-founded both in economics and in law; realistic political economy requires that we give it some credence, but not too much' (Krugman, [1997], p. 120). 
vide better deals for the acceding countries is wrong. EU entry is just the beginning, not the end of the story. The acquis communautaire consists of around 80,000 pages of EU legislation. ${ }^{7}$ The only possibilities for negotiation are the length of the adjustment period and the size of funds that may help its implementation. Agenda 2000 [1997], as the EU's overly optimistic plan for action in the medium term, is clear on this point. The new EU member country is expected to apply, implement and enforce the acquis communautaire upon accession. In order to safeguard EU competition rules, those measures that relate to the Single $M$ arket should be applied immediately upon accession. ${ }^{8}$ No derogations will be allowed to the new entrants. However, there may be certain transition measures for a limited period of time.

EU is already a two-speed organization. Countries that are in EM U form one tier, with B ritain, Denmark, Greece and Sweden (by choice or by ineligibility) forming another. Adding up another tier by derogations or opt-outs to the acceding transition countries would complicate the operation of EU and imperil free competition in the Single $M$ arket. Hence, according to Agenda 2000 this shall not happen. ${ }^{9}$ The applicant country's record in the implementation of existing commitments will be partly used by EU to judge the capacity to take on the obligations of membership. ${ }^{10}$

The fourth, tacit, requirement is that entry should not imperil the EU's financial resources, nor should widening of EU risk deepening of the integration process. If there are no changes in the EU policies and if the original four Visegrad countries enter EU, various estimates state that the annual transfers from EU to those countries would cost the EU budget around ECU 50 billion a year. ${ }^{11}$ That is about a half of the entire annual budget for $\mathrm{EU}(15)$.

The entry of the eastern European transition countries need not worry the EU M editerranean countries for at least another decade. The most developed of the 'new democracies' lag a lot behind the 'poorest' EU coun-

\section{Agence Europe, 3 D ecember 1998.}

8. European Commission [1997], p. 52.

9. European Commission [1997], p. 44, 51 and 134.

10. European Commission [1997], p. 45.

11. A short survey of select studies is given by Baldwin [1995]. 
tries (Portugal and Greece) in economic terms. Southern EU countries need not fear in the medium term the accession of select transition countries in the EU and the potential 'exodus' of jobs to central and eastern E urope because of lower wages there. ${ }^{12}$ If firms were looking for low-cost production, then China and India may be superior long-term choices than the transition countries in Europe. If relatively low wages were the determining factor for the location of production, then EU would be flooded with cheap goods from those countries. Factors such as productivity, the capital stock and stability often play a more decisive role for investors than wages. The southern EU countries are well ahead of the transition countries in those matters. It is often forgotten that trade only alters the structure of employment among different industries and overall standard of living, i.e. the kind of jobs available, rather than the actual availability of jobs.

A similar debate on trade liberalization with M exico and the creation of the N orth American Free Trade Agreement (NAFTA) was going on in the United States (US) in the early 1990s. In spite of strong opposition by the US presidential candidate Ross Perot regarding the free trade agreement between the US and M exico and a loss of jobs in the American economy ('giant sucking sound' of jobs moving south), ${ }^{13}$ only 117,000 Americans have applied for the benefits offered to workers displaced by the free trade agreement. If compared with the 1.5 million who lose their jobs each year from factory closures, slack demand and corporate restructuring, ${ }^{14}$ the cost of adjustment to the agreement by the US does not seem too high. Free trade might have destroyed some jobs in the American textile industry which is 'labor intensive', but it created new ones in electronics or aeronautics.

The problem with such debates about the employment effect of trade liberalization (in the countries with the developed and stable economies) are based on 'a fallacy of composition, that the effect of productivity increase in a given industry on the number of jobs in that industry is very different from the effect of a productivity increase in the economy as a whole on the total number of jobs' (Krugman, [1998], pp. 16-7). The negative impact of jobs

12. With 18 million EU citizen out of work in [1999], the sensitivity of the issue does not come as a surprise.

13. The E conomist, September 18, 1993, p. 51.

14. The E conomist, July 5, 1997, p. 17. 
going 'south' on a large scale has not materialized in practice and the net effect on the US job market might have been even positive.

The most important argument about the employment impact of the eastern enlargement of EU has, unfortunately, not yet made its way into the public consciousness. It also put certain academic debates on the wrong foot. The eastern enlargement may create new or keep the existing 'higher quality' jobs in EU. Isolated and highly publicized stories about the closure of a firm due to the enlargement are not typical for the whole EU economy. Those stories need to be seen in the context of the big picture. Because of the start of EMU in the majority of the EU countries, the average unemployment rate over the coming years will be what the European Central Bank wants it to be. The bank may pay little or no regard to the situation in the EU trade balance with the acceding transition countries.

In order to assist prospective transition countries, the Essen summit of 1994 outlined the 'pre-accession strategy' of EU. The key element is the assistance to the select group of transition countries. The prospective central European member countries committed themselves, among other things, to approximate their legislation to that of EU. The gap in the political, economic and social organization and development between EU and the potential new members has to nar row, otherwise the new members may not assume the full set of obligations and enjoy all the benefits of membership. Europe Agreements, a structured dialogue and the Phare Programme are the major tools of the 'pre-accession strategy'. ${ }^{15}$ In addition, the Cannes summit [1995] endorsed the White Paper, a reference document that can guide the prospective member countries through the labyrinth of EU legislation in order to make the task simpler.

15. There are concerns that the acceding transition countries do not always have the institutional capacity to absorb the financial opportunities provided by the Phare Programme. To obtain funds (aid), the acceding country has to make reforms and submit sensible projects to EU. As the submitted Polish projects were ill prepared, EU cut ECU 34 million off the planned aid of ECU 212 million for that country for 1998 (The E conomist, J une 6, 1998, pp. 37-8). As the cut of funds to a Phare country happened for the first time ever, EU sent a strong signal to the acceding transition countries that they need a serious institutional overhaul if they want to meet the high EU criteria. 
The European Commission sent a 200-page questionnaire to the potential member countries in order to assess their eligibility for membership. The answers constituted an important input into the preparations of formal opinions about eligibility for entry. A part from the opinion about the eligibility of each country, the Commission is in charge of preparing three other documents. The first one deals with the impact of the enlargement on $E U$, the second considers the financial framework, while the third, a composite document, is to offer a general assessment. In addition, in order to ease the potential entr $y, E U$ opened the Technical Assistance Information Exchange Office (TAIEX) in 1996. That is a one-stop shop for information and techni$\mathrm{cal} /$ legal advice on EU legislation, enforcement and infrastructure.

All the necessary conditions for entry into EU reveal that the Union has very high discretionary powers and flexibility in selecting would-be members. Those rights were used in July 1997 when EU invited Cyprus, the Czech Republic, Estonia, Hungary, Poland and Slovenia to start entry negotiations in 1998.

\section{Costs and Benefits}

\section{A. Acceding Countries}

Transition economies share political, security and economic reasons for joining EU. Politically, the transition countries have a still young and relatively fragile democratic system. Fragility comes from unfulfilled grand hopes that the change for the better towards a market-type democratic system can take place in a relatively short period of time and at a relatively modest cost. Although the immediate threat of armed conflict is not highly likely, there is still apprehension regarding the division of 'spheres of influence' between the West (EU and, principally, Germany) and Russia. The central, eastern European and Baltic States obtained their freedom from the 'eastern bloc'. They have concerns both about preserving their independence and about 'losing' that independence to the West.

As for the economic issues, there are gains and costs for the acceding countries from entry of EU.

- The major benefit for the $5+1$ countries would be secure access to the 
huge market of EU. This is particularly relevant for the goods that are 'sensitive' for EU (farm products, textile, steel, chemicals) as the $5+1$ countries have comparative advantage in the production of those goods. Entry would mean a kind of 'insurance policy' that the EU trade regime would remain open for their exports.

- The second gain would be the possibility of the migration of labor into the rest of $\mathrm{EU}$ following the specified adjustment period. This may, however, have a two-edged effect. If the educated and the experienced leave the transition countries, the productivity in the 'transition region' would suffer and funds for the education of experts would be lost. A relatively tight labor market in the rest of EU(15) would prevent such a scenario. In addition, experience has shown that labor migration (wars apart) takes place chiefly when labor cannot find employment in its country of origin.

- A third benefit from entry includes access to the structural and other funds of EU. This would all give an impetus to the strengthening of the market system (van Brabant, 1996).

\section{1) Structural Aid}

All those gains are not without risks. In some cases, the costs are quite serious. Transition countries still have fragile economies that would be exposed to fierce competition in the Single $M$ arket. Adjustment troubles are well-known even for the relatively advanced transition economy of eastern Germany after the Anschluss of 1989. Gross annual transfers from the western part of the reunified Germany to the east were around DM 170 billion during the 1990s (Table 4). Such massive aid to the former East Germany will be necessary for at least another five years in order to adjust its economy and catch up with the rest of the country. There were certain results regarding this 'catch up' process (Table 5). However, the financial cost was immense. There remains a question if such massive aid is necessary in the medium and long term. Aid may kill local incentives to adjust and it may create a structurally dependent economy out of the former East Germany as was the case with the Italian M ezzogiorno. If the relatively advanced eastern Germany needs such massive transfers, one trembles to think about the potential transfers to other acceding transition countries. ${ }^{16}$

Bearing in mind all these issues, one may ask if the acceding transition 


\section{Table 4}

\section{Annual Public Financial Transfers* from \\ Western to the Eastern Part of Germany (1991-97)}

(unit: \%)

\begin{tabular}{|l|c|c|c|c|c|c|c|}
\hline Transfer & 1991 & 1992 & 1993 & 1994 & 1995 & 1996 & 1997 \\
\hline Gross & 139 & 152 & 168 & 168 & 185 & 187 & 180 \\
Net & 106 & 115 & 129 & 125 & 140 & 140 & 133 \\
\hline
\end{tabular}

* Including social insurance.

Source: Herausgeber BMI [1998], Jahresbericht der Bundesregierung zum Stand der Deutschen Einheit. Berlin.

Table 5

Convergence Indicators for E ast Germany 1991 and1996

(West Germany=100)

\begin{tabular}{|l|c|c|}
\hline Indicator & 1991 & 1996 \\
\hline Average monthly wages & 48.3 & 76.7 \\
Gross & 54.8 & 82.4 \\
Net & & \\
Productivity & 30.0 & 56.7 \\
Total economy & 28.8 & 61.2 \\
M anufacturing and construction & 31.3 & 54.0 \\
GDP per capita at current prices & & \\
\hline
\end{tabular}

Source: Economic Commission for Europe [1997], Economic Survey for Europe in 19961997, N ew York: United Nations, p. 30.

countries are not, perhaps, aspiring to do too much too soon? O ne does not know where the funds to accommodate the transition countries could come from. The M aastricht criteria for EM U require budgetary cuts throughout the EU. The Cannes summit [1995] allocated 'only' ECU 6.7 billion to the

16. If the rules on regional aid from EU are not changed, then such type of aid to the acceding transition countries would transfer resources that are equal to $10-20 \%$ of the new members' GDP. That is far more than 3.5\% of GDP that Greece received in 1996 (The Economist, August 3, 1996, p. 28). Agenda 2000 limited the level of annual structural and cohesion aid to 4 per cent of the recipient country's GDP (European Commission [1997], p. 25). 
Phare Programme for the period 1995-99. Therefore, most of the funds should come from the acceding countries themselves.

As for the period 2000-06, there is a decision to keep the limit for spending for all EU activities on the level of $1.27 \%$ of the total GDP of the 15 member countries. This limit is combined with strict constraints on the national public expenditure that are related to EMU. However, Agenda 2000 earmarked ECU 45 billion for the period 2000-06 (a kind of mini M arshall Plan) as the pre-accession aid to the acceding $5+1$ countries. During that time, acceding countries will be granted ECU 1 billion a year as structural aid plus ECU 0.5 billion a year for agricultural development. ${ }^{17}$ The future negotiations about financing of $\mathrm{EU}$ expenditure will be more difficult than was the case in the past. EU member governments will argue against an expansion of the EU budget during times when they are making unprecedented efforts at home to cut spending in order to qualify for and stay in the EMU.

In theory, economic integration may, but will not necessarily, bring greater benefits to the regions/ countries that lag behind the centre of economic activity in their development. However, if production linkages (forward and backward) are strong and internal to an industry such as in chemicals or financial services and imperfect competition prevails, economic integration would trigger agglomeration tendencies. If those linkages are not limited to a relatively narrow industry group but are strong across industries and sectors, integration would produce agglomeration tendencies in select spots. If labor is not mobile, the whole process would tend to open up new and widen the existing regional wage differentials (Venables, [1996]). Although this may produce deindustrialization tendencies in the peripheral regions, it does not mean that integration is not desirable. For instance, education and regional policies increased the attractiveness of Spain as a location for various manufacturing industries, as discovered by EU and foreign investors.

Dispersion of industries takes place in the case with high cost of trade. When this cost is reduced, agglomeration can take place as demand in distant places can be met by exports. When the cost of trade approaches zero (as is the case in writing computer software in Bangalore, India and the use

17. European Commission [1997], p. 25 and 53. 
of Internet), footloose production may be dispersed and located according to the availability of the specific resource inputs. Globalization of certain industries (integrated international production) reduces the weight of physical proximity between various production units, as well as between producers and consumers.

Deepening of economic integration in $\mathrm{EU}$ through the elimination of nontariff barriers through the Single $M$ arket, reduction in the cost of transportation and EMU may diminish motives for regional and national self-sufficiency. However, integration may also stimulate agglomeration tendencies and reinforce the core-periphery problem. Production in EU may resemble that of US where industrial output (both in manufacturing and in services) is concentrated in distinct locations. Hence, if this in fact takes place in the future, internal EU trade among its member countries will no longer be intra-industry in nature, but rather inter-industry. Further reduction of trade costs in EU may lead to further concentration of production, which is subject to the economies of scale in the already existing core locations, while periphery may specialize in the manufacturing production that does not depend on scale economies (B rülhart and Torstensson, 1996, p. iii).

Statistical evidence gives support to the assumption of a negative relationship between intra-industry trade and industries characterized by economies of scale. However, this tendency was reversed in the 1980s and became hump ( $\cap$ shaped in peripheral regions of $E U$ (Brülhart and Torstensson, [1996] pp. 17-18). Certain regions may be losers for a (transitory) period of time, even though the group as a whole may be a net welfare gainer. But if the changing structure of regional employment has impact on wages, then there is a point where the periphery may be interesting for certain industries and attract them. The incentive may be unimpeded access to the market and lower labor costs. These industries do not necessarily need to be the ones that are scale-sensitive, because the industries that are subject to large increasing returns have already been well established in the core of EU. Such U-shaped relation between agglomeration and economic integration may be a part of the explanation why Spain attracted a relatively large number of foreign investors. Such kind of reasoning and regional compensation funds of the group may be used in convincing the adversely affected peripheral regions to put up with hard transition times that may fol- 
low trade liberalization and economic integration (Puga and Venables, [1997] p. 364). Similar trends remain in both for the current EU(15) member countries and the acceding countries from central and eastern Europe.

Others, however, may argue that the outcome could be reversed from that just described and that an active regional policy is necessary, in particular in EMU. The flow of emigrants would discourage the entry of new businesses into the region which would further weaken the economic position of the area in question. Nonetheless, such a vicious circle does not yet exist in $\mathrm{EU}$. What seems likely to be the case in $\mathrm{EU}$ is that the regional disparities were slowly narrowing until the early 1970s; this was followed by a decade-long period of widening the regional gaps; and than a stabilization of regional gaps between member countries..$^{18}$

One of the outcomes of the Single M arket was that clusters of firms and industries in EU became more visible. Relatively high geographic concentration of related firms in relatively small areas eased exchange of information. Following these changes, Frankfurt, London and Paris are the areas that create jobs faster than the rest of the national economy. However, the problem is in the regions outside a large metropolitan area which still seem to remain 'poor'. Success, like many other things, also appears to cluster.

\section{2) Acquis Communautaire}

Economic transition towards a market-type system is a lengthy and costly process. The acceptance and implementation of a continuously evolving the acquis communautaire is costly not only for the new members, but also for the countries that are already in EU. Being less developed, the transition countries have both a lower financial capacity and higher requirements to incorporate the $\mathrm{EU}$ rules. $\mathrm{M}$ any things are highly regulated in EU. They include not only health, environment and consumer protection, but also safety at work and social standards. M any of those issues do not directly increase productivity. With an out-of-date capital stock, there is a dilemma in the acceding transition countries. Should they invest scarce capital first

18. E conomic history of integrated states such as US points to the fact that integration is associated with regional convergence, which predominates over economic divergence in the long run. This process is rather slow, around $2 \%$ a year, but it is sustained over a long period of time (Barro and Sala-i-M artin [1991], p. 154). 
into upgrading output potential or do something else or both (in what proportion) $?^{19}$

The environmental dimension of the acquis communautaire has 320 pieces of 'green' legislation. ${ }^{20}$ To implement those laws could cost the 10 applicant transition countries as much as ECU 120 billion. ${ }^{21}$ Table 6 provides information on a part of these costs that deal with water, air and waste standards in EU in the five acceding countries. EU will offer certain funds to these countries to ease the financial burden to meet the entry criteria, but most of the funds will have to come from the new member countries themselves. ${ }^{22}$ Can these costs be compensated for by the potential benefits that would come from the entry? If so, how can one measure that? How long would it take? Is such an investment justified at this moment? Public opinion polls in transition countries rank care for the environment ${ }^{23}$ much lower than health care, education, security and the economy. ${ }^{24}$

Following these data and in comparison with EU (15), several acceding transition countries are not only worse off by a degree, but they still constitute a distinct class by themselves (B auer [1998], p. 11). The difference between the

19. It is true that not all the measures are to be accepted and implemented by the newcomers before entry.

20. There are discussions among Austria, Denmark, Finland, Germany, the Netherlands and Sweden about a possible creation of an 'Eco-Schengen' Group with the aim at coordinating the implementation of the existing legislation and introduction of new laws that have an impact on the environment.

21. European Voice, September 24, 1998, p. 15.

22. Compliance with those standards refers to all member countries of EU. For example, the privatized British water industry is expected to spend around $\$ 60$ billion between 1989 and 2004 to bring its water supply network into line with EU directives (The Financial Times, October 6, 1997, p. 18).

23. Agenda 2000 states that the environment is a major challenge for enlargement (European Commission [1997], p. 49).

24. A survey (by the author) of the five acceding transition countries, carried out in 1998, revealed that these countries know how much they can get from EU funds, but they had no estimates about the cost of the application of the acquis communautaire. The situation is Cyprus is different. The government has an estimate about the financial cost of the application of the acquis communautaire (which is for the time being kept as an element for the exchange of information with EU), but does not know the volume of funds that it may get from EU in order to meet the conditions from the acquis communautaire. 
Table 6

What Will Cost to Reach Environmental Standards for Accession

(ECU billion)

\begin{tabular}{|l|c|c|c|c|c|}
\hline Country & Water & Air & $\begin{array}{c}\text { Waste } \\
\text { (maximum) }\end{array}$ & $\begin{array}{c}\text { Total Investment } \\
\text { (maximum) }\end{array}$ & $\begin{array}{c}\text { Total ECU } \\
\text { per Capita }\end{array}$ \\
\hline Poland & 18.1 & 13.9 & 3.3 & 35.2 & 927 \\
Hungary & 6.6 & 2.7 & 4.4 & 13.7 & 1,306 \\
Czech R. & 3.3 & 6.4 & 3.8 & 12.4 & 1,427 \\
Slovakia & 1.9 & 1.9 & 1.6 & 5.4 & 760 \\
Estonia & 1.5 & n.a. & n.a. & 1.5 & n.a. \\
Slovenia & n.a. & 0.7 & 1.1 & 1.8 & n.a. \\
\hline
\end{tabular}

Source: Parlement européen [1998], "La politique de l'environnement et l'élargissement", Fiche thématique no. 17, Luxembourg, $23 \mathrm{M}$ arch, p. 15.

economies of the transition countries and that of $E U(15)$ is still huge.

According to Agenda 2000, EU does not expect any major problem regarding the adoption of the acquis communautaire in the southern part of Cyprus. However, there is a need for the alignment of regulations and practices in the financial sector. Income per capita in the northern part of the country is just one third that of the southern part. Another issue is the predominance of the public sector in the economy of the northern part of the country. 25

\section{3) Economic and Monetary Union}

The theory of international monetary integration is based on criteria which include factor mobility, openness of the economy, similar rates of unemployment, diversification of the economic structure, coordination of economic policies and comparable rates of inflation between the integrating countries (J ovanović [1998], pp. 170-185). The M aastricht Treaty brought conditions for $\mathrm{EM} \mathrm{U}$ that are not known in the theory of monetary integration. A sceptic might say that this is the reason why EM U may work! In any case, if transaction costs are significant and if there is a danger that comes from the exchange risk, then EMU can give an additional impetus to the

25. European Commission [1997], p. 54. 
expansion of the intra-EU trade.

The $M$ aastricht criteria for the EM U are the following:

- a high degree of price stability (low inflation)

- sound public finance position (budget deficit of maximum 3 per cent of the GDP)

- national debt of less than $60 \%$ of GDP

- no devaluation within the exchange rate mechanism for at least two preceding years

- national interest rate needs to be within the $2 \%$ margin of the three best performing countries.

The criteria for EM U may create barriers for the accession to the EU for many transition countries for a long time in the future. Agenda 2000 states that each acceding country is expected to apply, implement and enforce the acquis communautaire upon accession. In order to safeguard EU competition rules, those measures that relate to the Single $M$ arket should be applied immediately upon accession. ${ }^{26}$ Being out of EMU, a new member country's currency may be the target for a speculative attack on the currency market which the country may not be able to withstand. The country may alter the rate of exchange. By doing so, trade flows and free competition in the Single $M$ arket could be jeopardized. Hence the need for the acceding countries to join EMU. The four EU member countries that are currently out of EMU should not be taken as precedents for the acceding countries. The 'four' are already EU members and the Union has no declared intentions to enlarge the non-EMU tier in EU; on the contrar $\mathrm{y}$.

If the macroeconomic situation remains stable in the future, the $5+1$ acceding countries would not have big problems to satisfy most of the loosely interpreted $\mathrm{M}$ aastricht criteria for the EM U (Tables 7 and 8, respectively). ${ }^{27}$ All $5+1$ countries are growing economies. However, compared to the EMU requirements, all but Cyprus fail the price stability test. Inflation is still high and persisting compared to the EU criteria for a single currency.

26. European Commission [1997], p. 52.

27. Some of the Maastricht criteria are loosely interpreted as national debt was over $120 \%$ of the GDP in [1997] both in Belgium and in Italy, but both countries were permitted in [1998] to enter the EM U from the start, even though the M aastricht norm is $60 \%$ 
Table 7

Budget Deficit and National Debt in the European Union and the Acceding Countries (1996-98)

\begin{tabular}{|l|c|c|c|c|c|c|}
\hline \multirow{2}{*}{ Country } & \multicolumn{6}{|c|}{ \%of GDP } \\
\cline { 2 - 7 } & \multicolumn{3}{|c|}{ Budget deficit } & \multicolumn{3}{c|}{ National debt } \\
\cline { 2 - 7 } & 1996 & 1997 & 1998 & 1996 & 1997 & 1998 \\
\hline EU & 4.3 & 2.7 & 2.3 & 73.0 & 71.8 & 70.6 \\
Cyprus & 3.4 & 5.0 & 5.0 & 53.1 & 55.6 &.. \\
Czech Republic & 0.1 & 1.0 & 1.6 & 37.2 & 44.8 & 40.7 \\
Estonia & 1.5 & 2.0 & 1.4 & 5.6 & 5.4 & 5.5 \\
Hungary & 3.3 & 4.6 & 4.8 & 71.9 & 64.2 & 62.0 \\
Poland & 3.4 & 2.7 &.. & 48.1 & 45.5 & 49.0 \\
Slovenia & 0.3 & -1.1 & -1.0 & 28.8 &.. &.. \\
\hline
\end{tabular}

Source: National sources and E urostat

Table 8

GDP Growth Rate and Inflation in the European Union and the Acceding Countries (1996-98)

\begin{tabular}{|l|c|c|c|c|c|c|}
\hline \multirow{2}{*}{ Country } & \multicolumn{3}{|c|}{ Growth rate } & \multicolumn{3}{c|}{ Annual inflation } \\
\cline { 2 - 7 } & 1996 & 1997 & 1998 & 1996 & 1997 & 1998 \\
\hline EU & 1.8 & 2.7 & 2.8 & 2.6 & 1.8 & 1.5 \\
Cyprus & 2.2 & 2.5 & 4.7 & 3.0 & 3.6 & 2.3 \\
Czech Republic & 3.9 & 1.0 & -2.6 & 8.8 & 8.5 & 10.7 \\
Estonia & 4.0 & 9.9 & 5.5 & 17.6 & 11.2 & 10.0 \\
Hungary & 1.3 & 4.4 & 5.0 & 19.8 & 18.4 & 10.3 \\
Poland & 6.0 & 6.8 & 5.6 & 19.9 & 14.9 & 11.8 \\
Slovenia & 3.3 & 3.8 & 4.0 & 9.7 & 9.1 & 8.1 \\
\hline
\end{tabular}

Source: N ational sources and Eurostat

Apart from Cyprus and, perhaps Estonia, exchange rates cannot yet be taken as highly stabile.

A fall in the budget deficit ratio in the EU countries below the Maastricht norm of 3 per cent of GDP and the decline in the debt ratio has occurred in the past few years in many countries (in some cases this was partly due to one-off 
measures). There is still certain anxiety about the sustainability of such trends.

\section{4) Agriculture}

Farm gate prices in the acceding transition countries were on the average within a range of 40 to $80 \%$ of the EU level which is guaranteed by the Union's Common Agricultural Policy (CAP). ${ }^{28}$ If CAP prices apply directly in the acceding transition countries, that would give a strong boost to output of both crop (cereals, oilseeds and sugar) and livestock production, together with milk. At the same time, an increase in prices of farm goods in the acceding transition countries may provoke social tensions. These price hikes would hit hard social groups such as the retired and the unemployed, unless their income situation is improved. However, it would be difficult to convince the acceding countries not to increase farm production, unless they can see clear signs that CAP is changing prior to their entry. One thing is clear: enlargement of EU cannot easily proceed without a prior change in CAP. A deep reform of CAP will test the actual seriousness of EU about enlargement.

Reform of CAP represents one of the most serious challenges for EU. It will have consequences both on the internal operation, external economic relations and enlargement. Proposals of March 1998 may bring the most thorough reform of CAP since its inception in the mid-1960s. It is planned to cut intervention prices for farm goods up to $30 \%$ from the $2000-01$ season.

The eastern enlargement would also introduce a practical problem on how to operate country-specific transitional arrangements. If, for example, alignment of the prices of agricultural products between EU and Hungary takes place at a different rate from alignment of prices in Poland, it would be necessary to impose tariffs, not only between the acceding countries and $\mathrm{EU}(15)$, but also between the acceding countries themselves. ${ }^{29}$

CAP was introduced in the 1960s as an instrument for the security of food supplies and a means for the protection of income of farmers. As food shortages were eliminated and EU started disposing of surpluses and as farmers' income were safeguarded on the average against unfavorable developments, the EU concern shifted towards food safety and protection of

28. European E conomy [1997a], p. 8.

29. European E conomy [1997a], p. 25. 
the environment. This last concern is of great importance, as the acceding transition countries have a legacy of serious environmental damage.

\section{5) Corporate Governance and Institutional Reform}

Even though the enterprises of the acceding transition countries have been formally privatized to a large extent, they still do not operate in the way that is expected in a truly market economy. They still lack good corporate governance. All this cannot be introduced by decree. It is the product of a gradual evolution. The rights of owners in the market economies are protected by company laws, registration and listing requirements at the stock exchange, as well as by court procedures and enforcement of rulings. Provisions require firms to adopt certain corporate governance methods. The development of a capital market attractive to all investors depends in part on the level of protection of rights and legal interests of shareholders and investors. Shareholders require protection against capital market crimes such as frauding investors and operation without a licence.

Although obrious progress towards a market economy has been made in the acceding transition countries during the past decade, they still have to refer to the following points that can act as benchmarks for the national legislation relating good corporate governance:

- Rules for the conduct of enterprises need to be transparent.

- Corporations should ensure that registered shares are duly and properly recorded according to regulations (and that shares are free of error and protected from tampering).

- All shareholders should be treated equally. This right should be safeguarded through pre-emptive rights of all shareholders to acquire new shares and other measures designed to prevent the dilution of their economic interest in the corporation. Exceptions to this principle should be permissible only in the case of favorable solutions of shareholders whose rights are affected.

- Trading based on insider information needs to be outlawed.

- Shareholders should be provided with the information they require without delay and unreasonable cost. Quarterly distribution of main business indicators to shareholders is a common practice. Corporations should furnish shareholders with evidence of their shareholdings, permit access 
to the registers of shares and facilitate the transfer of shares.

- At shareholder meetings the shareholders and other interest groups/ stakeholders should have the right to obtain information about the performance of the enterprise in the past period, its future strategy, expected yields and to ask other questions. These meetings are an institutionalized way of involving shareholders in the decision-making process. The Board of Directors has to justify its way of running the company and share the visions of the future business to attract capital from potential creditors.

- Punishments need to be in place for capital market-related crimes, which include fraud and operation without a liscence.

\section{B. E uropean Union}

EU is generally interested in enlargement for various political, security, ecology and economic reasons. What, however, $5+1$ countries would specially contribute to the Union's economy is less easy to discern. Is the 'eastern' market with cheap labor and certain possibilities for investment an opportunity or a threat? It should be remembered that European integration started in the early 1950s, not for economic reasons, but rather for the preservation of peace. The political goal was to make war between Germany and France impossible through economic means. The southern enlargements of EU, although costly in financial terms, had the objective of stabilizing democracy in Greece, Spain and Portugal following a period of dictatorship. Identical arguments can be used regarding the potential eastern enlargement of $E U$. As for Cyprus, reunification of the country and a reduction in tensions in the eastern $M$ editerranean region may be some of the goals. Stability and predictability at the eastern border is in the interest of EU. Ecological and certain economic factors also apply. In addition, modernization of the transition economies may create and keep certain high technology jobs in manufacturing and services in EU(15).

The potential economic and political gains for EU need to be combined with at least two economic costs that are often mentioned.

- First is the need to finance the adjustment of the acceding countries to the acquis communautaire and to the M aastricht criteria for E M U. In a situa- 
tion with serious austerity measures in the EU countries, the question is, where the funds would come from?

- The second cost could come from the (potential) loss of jobs and business in the 'sensitive' manufacturing industries and in agriculture in EU because of the penetration of goods from the east. There may be strong lobby pressure on policy makers to slow down eastern enlargement and/ or request compensations from EU. This second 'cost' may be exaggerated. O wing to Europe Agreements, sensitive manufactured goods from the acceding countries now enter EU mainly free of tariff and quantitative restrictions. The major continuing barriers are chiefly anti-dumping measures. In addition, exports of sensitive products from the acceding countries to EU have not expanded relative to other products since the 1980s. Hence, one should not expect a surge in acceding countries' exports of sensitive manufactured products to $\mathrm{EU}$ as a consequence of further integration of these countries with the Union (Brenton and di M auro, [1998], p. 303).

When EU last accepted 'poor countries' (Spain and Portugal in 1986), the European Community, as it was then called, was not a single market for goods, services, capital and labor. EU deepened integration and EM U was introduced in 1999. Even though Spain and Portugal were 'poor', they were market economies. With this in mind, even the chances of the most advanced transition countries seem bleak for quite some time in the future, unless or until the entry rules change or the economic situation in the acceding transition countries improves. EU has few incentives and limited funds to accept countries with economic structures that are significantly different from its own. Such an attitude may seem hypocritical since the West has spent almost half a century encouraging those countries to join the free market and democratic world. Applicant countries need to exercise patience. An 'optimistic' timetable, if 'all goes well', meaning smooth negotiations of perhaps around a decade and an adjustment process of another decade, it would take the most advanced transition countries some 15-20 years to become full members of EU (J ovanović [1997a], p. 368)..$^{30}$

30. Long run growth projections predict that it may take around 30 years (one generation) for the central and east European countries to catch up with the income levels in low income EU countries (Fisher, Sahay and Végh [1998], p. 28). 
The overriding goal of EU is to safeguard the efficient operation of its Single $\mathrm{M}$ arket. This means that a multi-speed $\mathrm{EU}$ needs to be avoided as much as possible. Thus, there may be a sufficiently long pre-accession period tailored to the individual conditions of each new country in order to absorb the acquis communauitaire. This would eliminate the need for the unnecessary post-entry transition period. However, all this is highly speculative as the acquis communauitaire will be very different in the year 2010 from what it is today. Only in 1998 the acquis communautaire was 'enriched' by 2,866 regulations. It is true that most of them have a limited time duration. However, the new member countries have a race against ever-shifting goalposts. This would not be a problem for Cyprus as Agenda 2000 does not expect any major obstacle regarding the adoption, implementation and enforcement of the acquis communautaire in the southern part of the countr $y .{ }^{31}$

\section{Conclusion}

A plethora of agreements that EU has with the acceding transition countries offer improved access to the EU market. These technical agreements are a paradise for lawyers and consultants. However, such a variety of arrangements may complicate life. What may happen in the future is that EU would wish to place the glut of agreements with a single one, at least for the distinct groups of advanced acceding countries. These economies may be moving slowly towards the European Economic Area. Nonetheless, there is a lot of anxiety in the relations between EU and the acceding countries as there are still a number of economic and political risks and uncertainties. This is why the acceding $5+1$ countries now have a partnership with EU instead of membership.

The forthcoming Inter-governmental Conference will face the most thorough political reform of EU since its creation. It will have to deal with a number of political minefields on the way to preserving unity with diversity in EU. The Treaty of Amsterdam did not provide the expected solution of fundamental issues (institutional organization) that are linked with the forthcoming enlargement. It just postponed the solution for the future. The

31. European Commission [1997], p. 54. 
shadow of the Amsterdam 'success' may follow EU in the time to come. Has EU reached its limit? The Amsterdam experience may provide EU with new inspirations to try out something new and, potentially, create new grounds for European integration as envisaged in the Preamble of the Treaty of Rome.

Consideration of the issue of timing and terms of the new enlargement of $\mathrm{EU}$ is highly speculative. ${ }^{32}$ Entry depends on the political will (and the funds) of the EU countries. However, the funds and the political will existed even when Spain and Portugal were negotiating entry with EU, but their entry took several years more that expected and almost an additional decade to get up to full speed with the rest of EU. In addition, the Iberian enlargement of EU was technically and economically much simpler than the potential accession of transition countries. Hence, all official statements about (very) early entry into EU, by around the year 2003, need to be taken with a pinch of salt.

EU as we know it is finished. However, what will come out of the Intergovernmental Conference is not yet known and may not be known until the very last moment of negotiations as has usually been the case in the past. As a rule, when F rance and Germany and perhaps another larger EU country reach an agreement during the very last minutes of negotiation, then they pull others into the deal. ${ }^{33}$ Only once the exact terms for the entry are known, will one be able to make an analysis about the potential (high) costs of eastern enlargement of the $\mathrm{EU}$.

EMU is a project for the 1990s. Assuming that EMU will not fall apart, reforms of CAP, regional spending and EU institutions are on the priority list for the following decade. Only once this all is done, enlargement may proceed. However, this does not rule out the possibility to have enlargement included as a project in the forthcoming decade.

Spain and recently France (with tacit support from a number of other countries) are explicitly cautious about the enlargement of EU. Spain has

32. Once the Treaty is revised, it needs to go through the national parliaments for ratification, even through referendums. M emories about the difficulties ratification with the $M$ aastricht Treaty are still quite fresh.

33. Recall that revisions of the Treaty have to be legally unanimous. 
two national fears that can be substantiated. First, there may be an inflow of cheap fruits and vegetables from the east in EU(15) which can risk Spain's market share for these goods. Second, expenditure from generous structural funds would be directed eastwards to the detriment of the beneficiaries in Spain. France has reservations about the overall capacity (among other things) of the acceding countries to take all the obligations that come from EU membership.

Is it necessary to move very fast with the eastern enlargement? It is true that the acceding transition countries have 'no other way' but to join EU. It is also true that they have survived a 'big boom' adjustment following the transition process. However, the 'big boom' was a one-time affair. Integration in $\mathrm{EU}$ is a constantly evolving process. Unless the acceding transition countries are well prepared, they may face similar problems to those that Germany encountered with the absorption of the eastern part of the country. The forthcoming enlargement of EU will be the best prepared enlargement to date. However, enlargement of EU is a highly charged political process that cannot be predicted with accuracy. Therefore, on the economic side, if Cyprus has any choice, it has to be careful if it wants to join the 'slow track' of entry negotiations with the acceding transition countries.

European integration has always been based on the political decision to secure peace and liberty in Europe. That is the purpose of EU, although many observers have forgotten it. European integration is to mitigate the impact of old rivalries and replace them by mutual economic advantage and social prosperity. The forthcoming enlargement would not bring EU extra efficiency or growth, it will neither create new jobs. ${ }^{34}$ Its basic objective is to give a certain support to friendly countries and governments in their reform and general stabilization process.

European integration has always been in the hands of national elites. That is why the treaties on which European integration is based are complicated and incomprehensible to the man in the street. When the national elites decide to defend Europe from various challenges, in particular exter-

34. If the most market-oriented, democratic and well run $5+1$ countries of the first wave enter the EU, they would increase the $E U$ population by $17 \%$ and would add just $3 \%$ to its GDP (The E conomist, N ovember 7, 1998, p. 18). 
nal ones coming from both west and south, the eastern enlargement of EU may gain momentum. The major importance for the national elites in EU countries is now to regain popular backing for the process of European integration. The resignation of the European Commission in M arch 1999 left a mess behind which may add to 'E uroscepticism'. Therefore, the forthcoming $5+1$ enlargement of EU deserves support, but speed is not so important as mistakes could be paid with a longer-term loss of confidence in European integration. F estina lente! (Hurry, slowly!)

\section{References}

Aver y, G., and F. Cameron [1998], The Enlargement of the E uropean Union, Sheffield, Academic Press.

Baldwin, R. [1995], "The Eastern Enlargement of the European Union," European Economic Review; pp. 474-481.

Barro, R. and X. Sala-i-M artin [1991], "Convergence Across States and Regions," Brookings Papers on E conomic Activity; pp. 107-182.

Bauer, P. [1998]. "Eastward Enlargement - Benefits and Costs of EU Entry for the Transition Countries," Intereconomics, January/ February; pp. 11-19.

B renton, P. and F. di M auro [1998], "Is there Any Potential in Trade in Sensitive Industrial Products between the CEECS and the EU?," World E conomy; pp. 285-304.

Brülhart, M . and J. Torstensson [1996], "Regional Integration, Scale E conomies and Industry Location in the European Union," CEPR Dis cussion Paper ; No. 1435.

CEPR [1992], "Is Bigger B etter?," The E conomics of EC E nlargement, London, Centre for Economic Policy Research.

Davenport, M. [1995], "Fostering Integration of Countries in Transition in Central and Eastern Europe in the World Economy and the Implications for the Developing Countries," UNCTAD, ITD/ 7, October 31, 1995.

Economic Commission for Europe [1996], Economic Bulletin for Europe, $\mathrm{N}$ ew York, U nited N ations.

Economic Commission for Europe [1997], Economic Survey for Europe in 1996-1997, New York, United Nations. 
E conomic Commission for Europe [1998], Economic Survey of Europe 1998, No.3, New York, United Nations.

European Commission [1997], Agenda 2000 for a Stronger and Wider Union, Luxembourg, European Communities.

European Economy [1997a], The CAP and Enlargement, No. 2.

European Economy [1997b], Towards a Common Agricultural and Rural Policy for Europe, N o. 5.

Fisher, S., R. Sahay and C. Végh [1998], "H ow Far is Eastern Europe from Brussels?," IM F Working Paper, WP/ 98/ 53.

Henriot, A. [1997], “Les Enjeux de L'élargissement de L'Union

Européenne," Le Courrier de Pays de L'Est, December; pp. 3-16.

Hertel, T., M . Brockmeier and P. Swaminathan [1997], "Sectoral and E conomy-wide Analysis of Integrating Central and Eastern European Countries into the EU: Implications of Alternative Strategies," European Review of Agricultural Economics; pp. 359-386.

Jovanović, M . [1997], European E conomic Integration: Limits and Prospects, London, Routledge.

Jovanović, M . [1997a], "Probing Leviathan: The Eastern Enlargement of the European Union," European Review; pp. 353-370.

Jovanović, M. [1998], International Economic Integration: Limits and Prospects, London, Routledge.

Jovanović, M. [1998a], "Does Eastern Enlargement M ean the End of the European Union?," International Relations; pp. 23-39.

Krugman, P. [1997], "What Should Trade Negotiators Negotiate About?," Journal of E conomic Literature; pp. 113-120.

Krugman, P. [1998], The Accidental Theorist, New York, N orton.

Lintner, V. [ 1995], "The Economic Implications of E nlarging the European Union," in The E conomics of the N ew Europe (ed.) N. Healey, London, Routledge; pp. 170-187.

Mayhew, A. [1998], Recreating Europe: The European Union's Policy towards Central and Eastern Europe, Cambridge, Cambridge U niversity Press. Nicolaides, P. [ 1999], "The E conomics of Enlarging the European Union: Policy Reform Versus Transfers," Intereconomics, January/ February; pp. 3-9.

Puga, D. and A. Venables [1997], "Preferential Trading Arrangements and 
Industrial Location," Journal of International E conomics; pp. 347-368.

Theophanous, A. [1996], The Political Economy of a Federal Cyprus, Nicosia, Intercollege Press.

van Brabant, J. [1996], "Remaking Europe - The Accession of Transition

Economies," E conomia Internazionale; pp. 507-531.

Venables, A. [1996], "Localization of Industry and Trade Performance," Oxford Review of Economic Policy; pp. 52-60. 